\title{
Study on Common Problems and Countermeasures of Construction Cost
}

\author{
Yanli Guo, a, Chengli Zhü, b \\ ${ }^{1}$ School of Yibin Vocational and Technical college, Yibin, Sichuan, 644000, China; \\ 2 Yibin Railway Construction Co., Ltd, Yibin, Sichuan, 644000, China. \\ a383009062@qq.com, b174344427@qq.com
}

\begin{abstract}
Keywords: Construction Engineering; Cost Management; Common Problems; Countermeasures.
\end{abstract}
\begin{abstract}
With the development of national economy, the market competition is becoming more and more fierce. Many construction enterprises will encounter some problems when reducing project cost to get better competition opportunity. From establishing the perfect management mechanism, strictly confirm approval personnel qualification, strengthen the construction process of cost control, as well as the strengthening of economy and technology, the article puts forward the effective method to implement construction project cost management, to ensure the sustainable development of construction enterprises.
\end{abstract}

\section{Introduction}

With the development of national economy and the continuous advancement of urbanization, construction enterprises have a good development opportunity, at the same time, the competition among construction enterprises has been increased. How to reduce the cost reasonably and control the cost scientifically, so as to improve the competitiveness of construction enterprises, has become a big problem faced by construction enterprises.

\section{Common Problems of Construction Cost}

\subsection{The Cost Management Department is Imperfect}

Affected by the competition in the construction market, many construction enterprises take various measures to reduce the construction cost to gain competitiveness. This often leads to a decline in the quality of construction projects. On the one hand, this phenomenon fully illustrates the many construction enterprises lack of scientific management system. They blindly use a single method of cost reduction to reduce the cost of the project, and they did not really play a scientific control on the cost of the project. On the other hand, this phenomenon from the side reflects a lot of cost management of construction enterprises to seriously insufficient. The management personnel on the ability and method can't meet the demand of the reality.

\subsection{The Project Cost Approval Process is not Rigorous Enough}

The examination and approval of project cost is the supervision and affirmation of project cost management. However, many construction enterprises have not set up a complete approval system. Moreover, engaged in engineering cost auditing staff most graduated from accounting major. And some employees have not received professional training before they start to work. They have little knowledge of construction costs. Construction enterprises also have a large number of fresh graduates who lack practical experience. They have poor ability to complete the task independently. This will inevitably reduce the accuracy and efficiency of the construction cost approval.

\subsection{Insufficient Control of Project Cost}

Project cost management runs through the whole process of construction projects. Many construction enterprises only pay attention to the cost budget before construction and the completion settlement after completion of the project. However, they ignored the cost control in the construction process. In case of change claims and other problems, if they cannot be controlled in time, they will inevitably bring large or small economic losses to the company. 


\subsection{Weak Information Management of Construction Enterprises}

Many construction enterprises do not have comprehensive information management. Information construction must be in line with the actual situation of enterprises, in order to play a real role and enhance the benefits of enterprises. However, the information construction of many construction enterprises still exists in the simple imitation of large enterprises, and does not take into account their actual conditions, which leads to the irrational use of information resources. At the same time, construction enterprises lack the real professional computer knowledge, and can actually carry out information construction for enterprises. The lack of systematic and continuous training for the existing computer talents leads to the failure of talents to play the biggest role.

\section{Countermeasures of Construction Project Cost Management}

Based on the above problems, this paper conducts in-depth analysis and combines with the practical problems of construction enterprises, classifies the problems into construction enterprise problems and specific construction project problems, as shown in figure 1 .

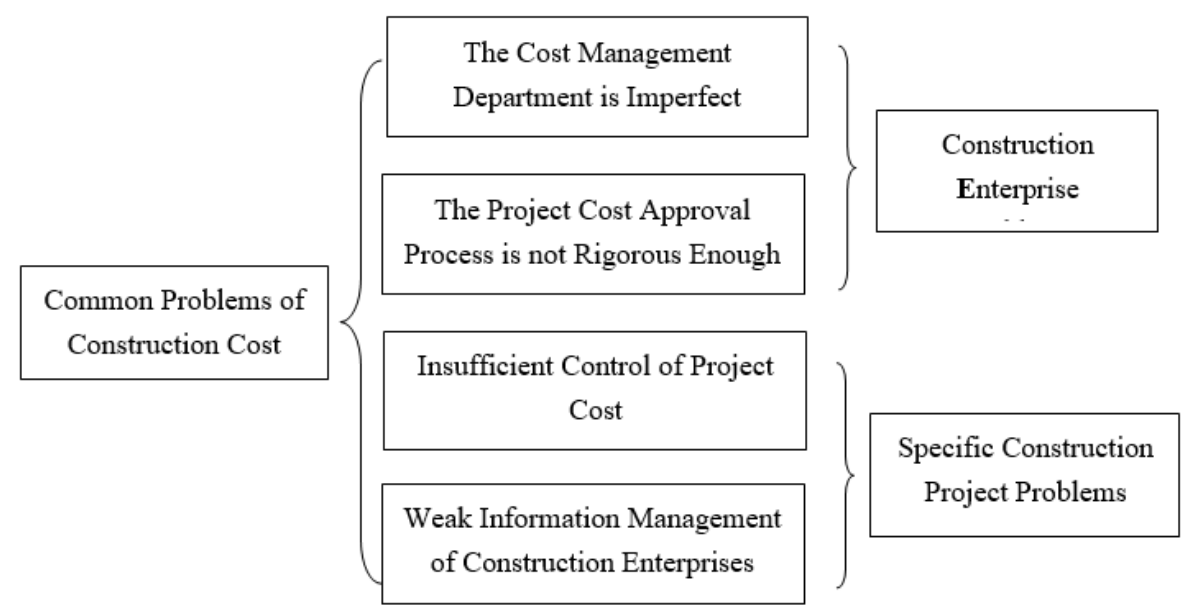

Fig 1. Classification of common problems in construction cost

Starting from the enterprise level and the construction project level, the following countermeasures are proposed.

\subsection{Construction Enterprise Level}

(1) Establish a Perfect Project Cost Management Organization

On the basis of understanding the importance of cost management, Construction enterprises should analyze the characteristics of specific projects, establish exclusive cost control methods for different projects, and improve the previous single cost control methods. At the same time, the construction enterprise shall be under the constraint of relevant laws and regulations, according to the enterprise's own situation, set up its cost management system. Moreover, construction enterprises should be stricter in recruiting people in the cost management system, who should have the ability to flexibly deal with complex events in real work.

(2) Strictly Ensure the Qualification of Project Cost Approval Personnel

In view of the lack of solid professional knowledge of construction cost examiners, we should strictly select project cost examiners from three aspects: professional counterpart, professional qualification and historical experience, and carry out strict professional knowledge training after entering the job. In order to ensure the scientific and reasonable project cost, in-depth training is carried out for the current project, so that the examiners can conduct cost approval on the basis of full understanding of the project.

\subsection{Construction Project Level}

(1) Strengthen the Information Management of Project Cost Control

In order to solve the problem of construction cost, it is necessary to master the relevant information accurately. With the rapid development of the Internet, the database has provided a lot of 
accurate information for various enterprises, which can help enterprises to understand the market more accurately and quickly. Therefore, it is necessary for construction enterprises to introduce talents from the Internet to establish an information platform for the engineering cost management of construction enterprises. So as to improve the information management of engineering cost and improve the accuracy of engineering cost.

(2) Strengthen Construction Process Cost Control

Construction project involves huge amount, construction cycle is long. It is inevitable that some unforeseen events will occur in the construction process, such as changes to the design drawings, the change of policies and regulations, and material prices fall sharply. These phenomena may lead to the deviation of investment. Therefore, great attention should be paid to problems that may appear at any time in the construction process. After the occurrence of the problem, the causes and consequences of the deviation will be accurately analyzed, the impact of the construction period and cost loss will be calculated, and the deviation will be corrected accordingly. In order to control the construction cost with the minimum loss.

(3) Strengthen the Integration of Economy and Technology

Construction management tends to be technical, while project cost tends to be controlled by economy. The organic combination of the two is more conducive to the overall completion of the construction project. Therefore, when carrying out construction management, the management will be more refined, and at the same time, attention should be paid to the control of construction cost. On the basis of improving the construction efficiency as much as possible, the construction cost should be controlled reasonably. Similarly, when conducting the project budget, the direction of each fund should be clearly defined, and the quality of the project should be guaranteed as low as possible at a lower cost. A better integration of economy and technology is the prerequisite for sustainable development of the construction market.

\section{Conclusion}

As the market competition becomes more and more fierce, many construction enterprises will inevitably encounter some problems when reducing the project cost to get a better competitive opportunity. This paper analyses the common problems and corresponding measures against these problems. From establishing the perfect management mechanism, strictly confirm approval personnel qualification, strengthen the construction process of cost control, as well as the strengthening of economy and technology, the article puts forward the effective method to implement construction project cost management, to ensure the sustainable development of construction enterprises.

\section{References}

[1]. Song Lixia, Wu Xiaohua. Dynamic Control of Construction Cost in Construction Stage Based on the Whole Process Cost Management [J]. The Construction Technology. 2016.

[2]. Xu Chao. Research on the Key Points and Management of Construction Project Cost Pre-Settlement Audit [J]. China's High-tech Enterprises. 2015(11).

[3]. Ma Jingyi. Application of Construction Economy in Cost Management [J]. China Building Materials Technology. 2016(5).

[4]. Li Yongnian, Yan Shuwei. The Problems and Countermeasures of the Cost of the Project are Discussed [J]. Value Engineering. 2012(25).

[5]. Liu Haimin. A Brief Analysis of the Construction Conditions, Methods and Budget Relationship [J]. China's Water Transport. 2015(15). 